\title{
Is the use of headless compression screws appropriate in arthroscopic ankle arthrodesis?
}

\author{
Başsız kompresyon vidası kullanımı artroskopik ayak bileği artrodezinde uygun mudur?
}

\author{
Durmuş Ali Öçgüder, MD., ${ }^{1}$ Ahmet Fırat, MD., ${ }^{1}$ Metin Özdemir, MD., ${ }^{2}$ Osman Tecimel, MD.1 \\ 'Department of Orthopedics and Traumatology, Ataturk Training and Research Hospital, Ankara, Turkey \\ 2Urofiz Physical Therapy and Rehabilitation Center, Ankara, Turkey
}

\begin{abstract}
Objectives: This study aims to evaluate whether the use of headless compression screws is appropriate in arthroscopic ankle arthrodesis.

Patients and methods: Twenty-two feet of 22 patients (12 males, 10 females; mean age 43.7 years; range 21 to 63 years) in whom we applied arthroscopic ankle arthrodesis were examined retrospectively. Mean follow-up duration was 59.3 months (range 36 to 92 months). Coronal and sagittal plane alignment and concomitant pathologies were evaluated on patients' radiographs. Assessments related to pain and functionality were performed by the American Orthopaedic Foot and Ankle Society (AOFAS) scoring.
\end{abstract}

Results: Radiographic union was achieved in 21 of the total 22 ankles $(95.4 \%)$. Mean time to union was $10.3 \pm 3.5$ weeks (range 6.6 to 13.8 weeks). Mean AOFAS pain score increased from $8.1 \pm 10.2$ to $35.0 \pm 6.3$ and functional score increased from $21.3 \pm 5.5$ to $43.4 \pm 3.8(\mathrm{p}<0.001)$. On coronal plane, preoperative tibiotalar angle of $6.6 \pm 5.5^{\circ}$ decreased to $2.3 \pm 2.1^{\circ}$ postoperatively. On sagittal plane, while preoperative tibiotalar angle was $17 \pm 4.9^{\circ}$, it was $17 \pm 4.5^{\circ}$ postoperatively. One patient had subtalar pain and one patient had nonunion postoperatively.

Conclusion: The use of headless compression screws is an appropriate choice in the ankle area owing to their advantages of providing successful fixation whilst not causing screw head irritation or pain.

Keywords: Ankle; arthrodesis; headless compression screw.

Ankle arthrodesis is a method applied to relieve pain and improve the functional results of advanced level arthritis in the ankle. ${ }^{[1]}$ Arthroscopic ankle arthrodesis provides rapid rehabilitation, faster bone

\section{ÖZ}

Amaç: $\mathrm{Bu}$ çalışmada artroskopik ayak bileği artrodezinde başsız kompresyon vidası kullanımının uygun olup olmadığı değerlendirildi.

Hastalar ve yöntemler: Artroskopik ayak bileği artrodezi uyguladığımız 22 hastanın (12 erkek; 10 kadın; ort. yaş 43.7 yıl; dağılım 21-63 yıl) 22 ayağı geriye dönük olarak incelendi. Ortalama takip süresi 59.3 ay (dağılım 36-92 ay) idi. Hastaların grafilerinde koronal ve sagittal düzlemdeki dizilim ve eşlik eden patolojiler değerlendirildi. A $\breve{g r} 1$ ve fonksiyonelliğe ilişkin değerlendirmeler Amerikan Ortopedik Ayak ve Ayak Bileği Derneği (AOFAS) skorlaması ile yapild 1 .

Bulgular: Toplam 22 ayak bileğinin 21'inde (\%95.4) radyolojik kaynama sağlandı. Ortalama kaynama süresi 10.3 \pm 3.5 hafta (dağ 1 lım 6.6-13.8 hafta) idi. Ortalama AOFAS ağrı skoru $8.1 \pm 10.2$ 'den $35.0 \pm 6.3$ 'e, fonksiyonel skoru $21.3 \pm 5.5$ 'ten $43.4 \pm 3.8$ 'e yükseldi $(\mathrm{p}<0.001)$. Koronal düzlemdeki ameliyat öncesi tibiotalar açı $6.6 \pm 5.5^{\circ}$ den ameliyat sonrası $2.3 \pm 2.1^{\circ}$ e düştü. Sagittal düzlemdeki ameliyat öncesi tibiotalar açı $17 \pm 4.9^{\circ}$ iken ameliyat sonrası $17 \pm 4.5^{\circ}$ idi. Ameliyat sonrası bir hastada subtalar ağrı ve bir hastada kaynamama vard1.

Sonuç: Başarılı tespit sağlaması, buna karşın vida başının iritasyon ve ağrıya neden olmaması avantajlarından dolayı ayak bileği bölgesinde başsız kompresyon vidaları kullanılması uygun bir seçenektir.

Anahtar sözcükler: Ayak bileği; artrodez; başsız kompresyon vidası.

union, reduced blood loss, shorter hospitalization time and reduced patient morbidity. ${ }^{[2-5]}$

Despite this increased popularity, there are still various problems for which the solutions remain

- Received: March 13, 2017 Accepted: August 24, 2017

- Correspondence: Durmuş Ali Öçgüder, MD. Atatürk Eğitim ve Araștırma Hastanesi Ortopedi ve Travmatoloji Kliniği, 06800 Çankaya, Ankara, Turkey. Tel: +90 505 - 4578788 e-mail: aliocguder@yahoo.com 
inadequate. These are insufficient compression and fixation on the arthrodesis surface, as well as difficulties relating to the appropriate location and positions for the fixation material, which can sometimes be felt under the skin and cause irritation. ${ }^{[4-6]}$ There are several studies in the literature regarding the fixation location and screw positions. ${ }^{[4,7]}$ The strength of the fixation is closely related with the issues of bony union and deformity prevention. Previous studies have reported the rate of secondary surgery for removal of symptomatic metalwork as 9 to $31 \%$. ${ }^{[4,5,7]}$ Second-look operations due to prominent metalwork decrease patient satisfaction. ${ }^{[4]}$ Although headless compression screws (HCS) are widely used during trauma surgeries, there is little evidence in the literature for their use in ankle arthrodesis. ${ }^{[8]}$ Therefore, in this study, we aimed to evaluate whether the use of HCSs is appropriate in arthroscopic ankle arthrodesis.

\section{PATIENTS AND METHODS}

The study retrospectively evaluated collective data of 22 feet of 22 patients (12 males, 10 females; mean age 43.7 years; range 21 to 63 years) who went through arthroscopic ankle arthrodesis at Atatürk Training and
Research Hospital between March 2008 and November 2012. Of the patients, $12(54.5 \%)$ had osteoarthritis based on post-traumatic arthritis, five $(22.7 \%)$ as a sequelae of poliomyelitis, three $(13.5 \%)$ as a sequelae of neuropathic foot and two $(9.9 \%)$ as a sequelae of septic arthritis. One patient with poliomyelitis sequelae had previously undergone triple arthrodesis and another patient had undergone subtalar arthrodesis surgery. In one patient, an additional closed wedge osteotomy was applied at the same time as the ankle arthrodesis due to accompanying pes cavus deformity associated with poliomyelitis sequelae (Table I). The study protocol was approved by the Atatürk Training and Research Hospital Ethics Committee. A written informed consent was obtained from each patient. The study was conducted in accordance with the principles of the Declaration of Helsinki.

Pre- and postoperative radiographic evaluations were performed using standard anteroposterior and lateral X-rays. In these images, bony union, coronal and sagittal plane alignment were measured (Figure 1a, b). The osseous bridging trabeculae in the arthrodesis area were evaluated for bone union. (Figure 2a, b). Concomitant additional pathologies were evaluated

TABLE I

Patient demographics

\begin{tabular}{|c|c|c|c|c|c|}
\hline Case & Age/Gender & Follow-up (month) & Etiology & Smoking & Body mass index \\
\hline 1 & $63 / \mathrm{M}$ & 92 & Posttraumatic arthritis & Yes & 32.1 \\
\hline 2 & $21 / \mathrm{M}$ & 36 & Poliomyelitis & No & 23.3 \\
\hline 3 & $34 / F$ & 62 & Septic arthritis & Yes & 27.3 \\
\hline 4 & $36 / M$ & 50 & Poliomyelitis & Yes & 22.5 \\
\hline 5 & $36 / \mathrm{M}$ & 64 & Posttraumatic arthritis & Yes & 32 \\
\hline 6 & $43 / F$ & 74 & Neuropathic foot & Yes & 30 \\
\hline 7 & $60 / \mathrm{M}$ & 63 & Posttraumatic arthritis & Yes & 30.2 \\
\hline 8 & $57 / F$ & 70 & Neuropathic foot & No & 24.6 \\
\hline 9 & $34 / \mathrm{M}$ & 68 & Neuropathic foot & No & 22.6 \\
\hline 10 & $44 / F$ & 42 & Poliomyelitis & Yes & 23.3 \\
\hline 11 & $54 / M$ & 36 & Posttraumatic arthritis & No & 31.2 \\
\hline 12 & $37 / F$ & 36 & Poliomyelitis & Yes & 24.7 \\
\hline 13 & $40 / F$ & 88 & Posttraumatic arthritis & Yes & 20.4 \\
\hline 14 & $43 / \mathrm{M}$ & 38 & Septic arthritis & No & 21.1 \\
\hline 15 & $45 / M$ & 49 & Posttraumatic arthritis & No & 30 \\
\hline 16 & $56 / \mathrm{M}$ & 58 & Posttraumatic arthritis & Yes & 20.7 \\
\hline 17 & $35 / F$ & 68 & Posttraumatic arthritis & Yes & 30.2 \\
\hline 18 & $37 / F$ & 71 & Posttraumatic arthritis & No & 22 \\
\hline 19 & $40 / \mathrm{M}$ & 69 & Poliomyelitis & No & 24.3 \\
\hline 20 & $44 / \mathrm{M}$ & 78 & Posttraumatic arthritis & Yes & 26.3 \\
\hline 21 & $53 / F$ & 52 & Posttraumatic arthritis & Yes & 25.2 \\
\hline 22 & $50 / F$ & 42 & Posttraumatic arthritis & Yes & 27.2 \\
\hline
\end{tabular}



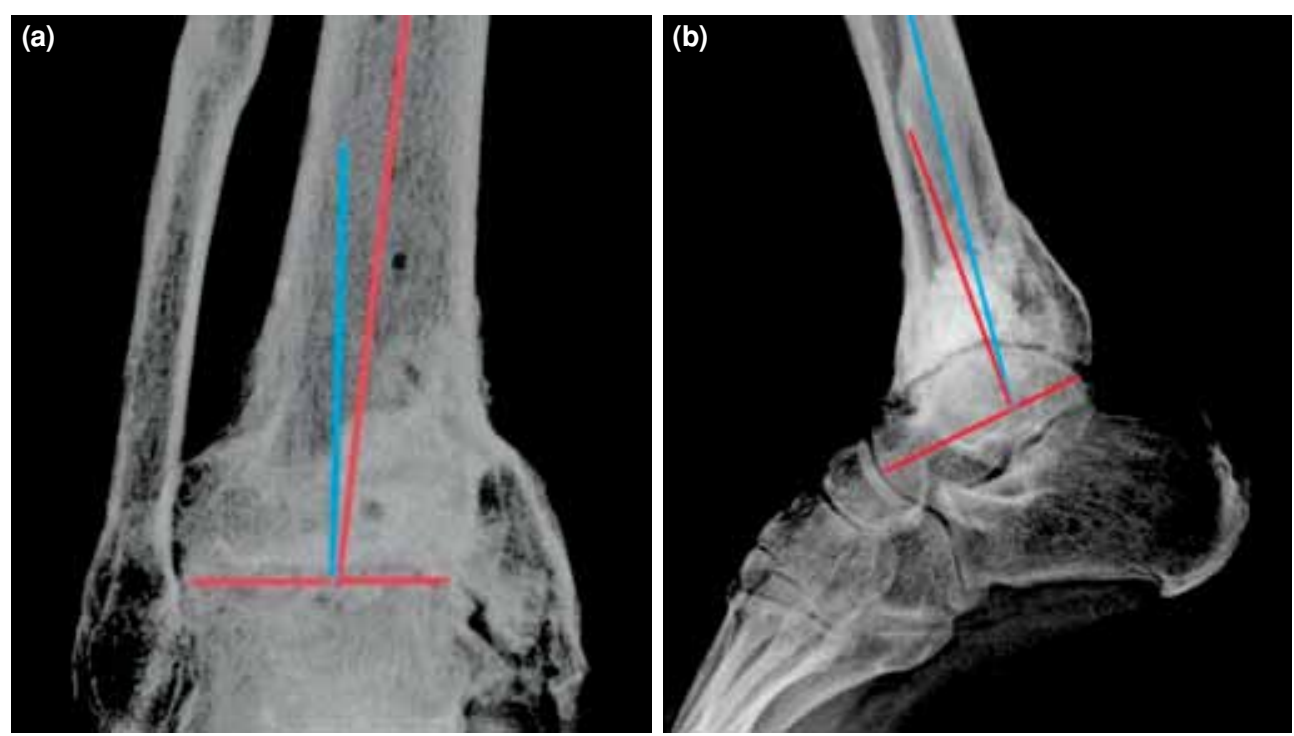

Figure 1. (a) Evaluation of coronal plane alignment. (b) Evaluation of sagittal plane alignment.

on the radiographs (Figure $3 a, b)$. Coronal alignment was measured as the angle between the anatomical axis of the tibia and the proximal talar subchondral surface on the anteroposterior radiograph. Sagittal alignment was measured as the angle between the anatomical axis of the tibia and the long axis of the talus as viewed on the lateral radiograph. Measurements were performed on neutral position both pre- and postoperatively. If the neutral position could not be achieved preoperatively because of contracture, the closest degree to neutral position was used and accepted as preoperative deformity degree.
The American Orthopaedic Foot and Ankle Society (AOFAS) scoring system was used in the evaluation of pre- and postoperative functional outcome. An independent author examined hardware irritation in the follow-up. Any complaints of prominent metalwork or palpable tenderness over the implant were considered as a positive finding. Implant removal for metalwork and complications were recorded.

Our surgical indication was tibiotalar arthritis that did not respond to conservative treatment over a period of six months preoperatively. An experienced
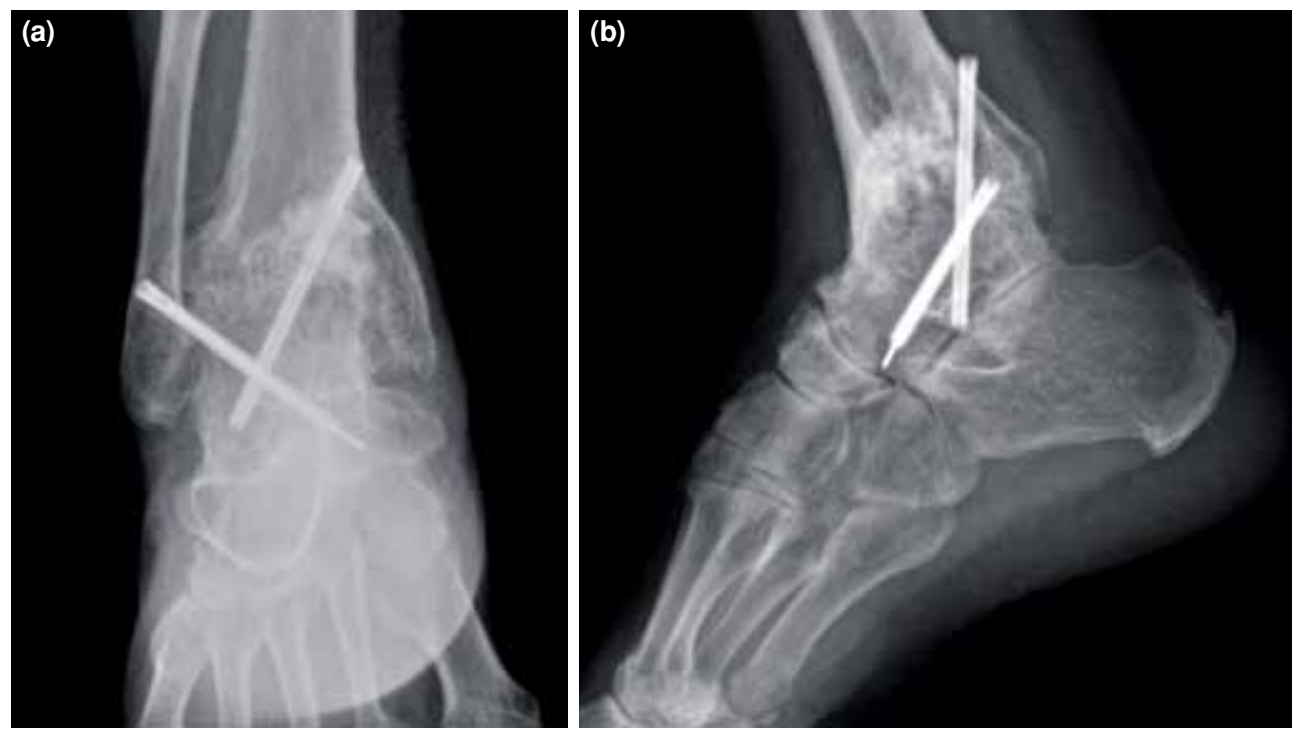

Figure 2. (a) Anteroposterior ankle radiograph of achieved union. (b) Lateral radiograph at the last follow-up (88 months). 

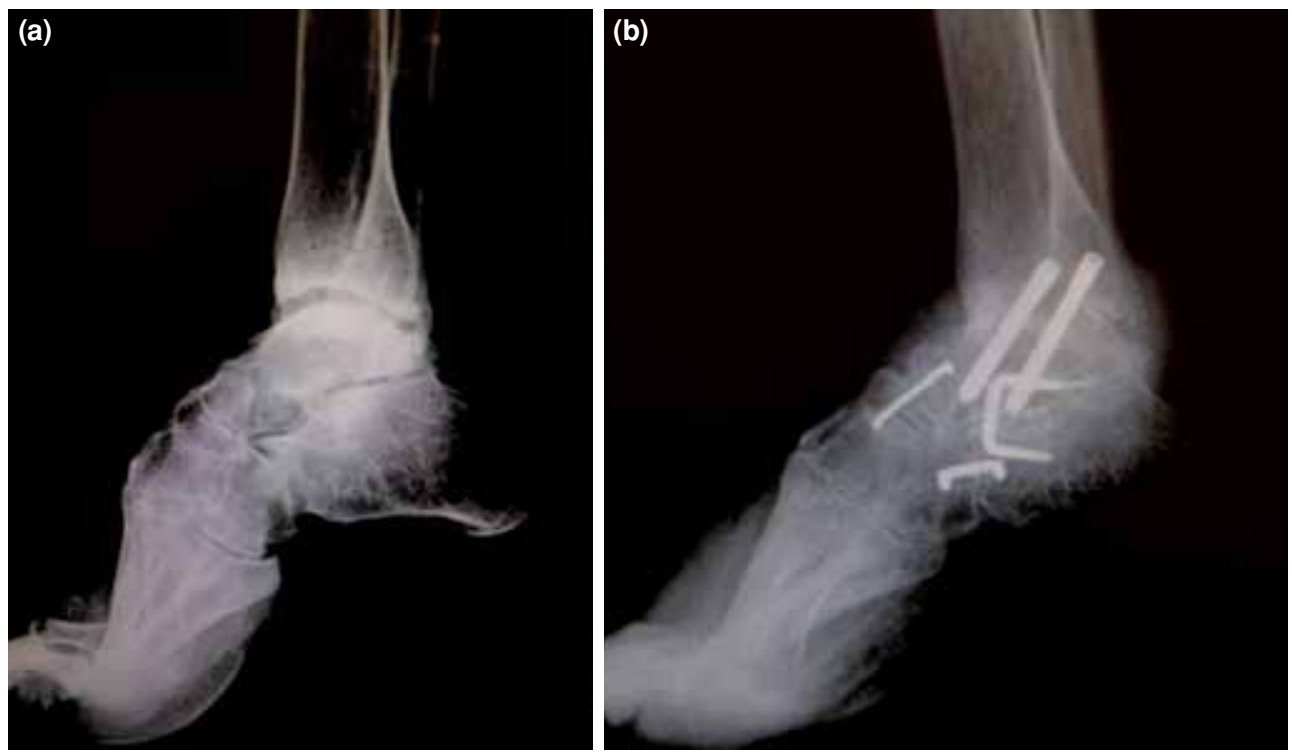

Figure 3. (a) Lateral radiograph of foot and ankle of a poliomyelitis patient with pes cavus. (b) Lateral radiograph of patient with pes cavus at last follow-up (36 months).

author performed all surgical procedures. Standard anterolateral and anteromedial portals were applied for the arthroscopic procedure. A $30^{\circ}, 2.9 \mathrm{~mm}$ arthroscope was used for visualization. Joint irrigation was achieved by setting the pump. The subchondral bone was prepared by removing the articular cartilage

TABLE II

Radiological and functional results

\begin{tabular}{|c|c|c|c|c|c|c|c|c|}
\hline Case & $\begin{array}{c}{ }^{*} \text { Pre- } \\
\text { CPA }\left(^{\circ}\right)\end{array}$ & $\begin{array}{l}{ }^{*} \text { Post- } \\
\text { CPA }\left(^{\circ}\right)\end{array}$ & $\begin{array}{c}\text { Pre- } \\
\text { SPA }\left(^{\circ}\right)\end{array}$ & $\begin{array}{l}\text { Post- } \\
\text { SPA }\left(^{\circ}\right)\end{array}$ & $\begin{array}{l}\text { Pre-AOFAS } \\
\text { pain score }\end{array}$ & $\begin{array}{l}\text { Post-AOFAS } \\
\text { pain score }\end{array}$ & $\begin{array}{c}\text { Pre-AOFAS } \\
\text { functional score }\end{array}$ & $\begin{array}{c}\text { Post-AOFAS } \\
\text { functional score }\end{array}$ \\
\hline 1 & 6 & 2 & 10 & 10 & 0 & 40 & 25 & 42 \\
\hline 2 & 8 & 4 & 20 & 14 & 0 & 30 & 35 & 39 \\
\hline 3 & 2 & 2 & 18 & 14 & 20 & 30 & 16 & 41 \\
\hline 4 & 8 & 6 & 22 & 20 & 20 & 30 & 19 & 38 \\
\hline 5 & 18 & 6 & 24 & 26 & 20 & 40 & 27 & 45 \\
\hline 6 & 2 & 0 & 22 & 20 & 0 & 30 & 17 & 50 \\
\hline 7 & 6 & 2 & 24 & 24 & 20 & 40 & 24 & 48 \\
\hline 8 & 20 & 5 & 22 & 20 & 0 & 40 & 19 & 44 \\
\hline 9 & 0 & 0 & 12 & 10 & 0 & 40 & 24 & 42 \\
\hline 10 & 2 & 0 & 22 & 20 & 20 & 40 & 27 & 44 \\
\hline 11 & 7 & 4 & 10 & 16 & 0 & 40 & 17 & 38 \\
\hline 12 & 8 & 2 & 16 & 14 & 0 & 30 & 25 & 41 \\
\hline 13 & 8 & 2 & 12 & 18 & 20 & 30 & 16 & 50 \\
\hline 14 & 3 & 0 & 14 & 16 & 0 & 20 & 25 & 39 \\
\hline 15 & 4 & 0 & 20 & 16 & 0 & 30 & 16 & 42 \\
\hline 16 & 4 & 1 & 20 & 20 & 20 & 40 & 17 & 42 \\
\hline 17 & 8 & 0 & 22 & 18 & 0 & 30 & 16 & 39 \\
\hline 18 & 8 & 6 & 18 & 14 & 0 & 40 & 25 & 45 \\
\hline 19 & 2 & 2 & 10 & 20 & 20 & 40 & 17 & 50 \\
\hline 20 & 6 & 2 & 12 & 20 & 0 & 30 & 29 & 48 \\
\hline 21 & 8 & 5 & 20 & 14 & 20 & 40 & 17 & 44 \\
\hline 22 & 4 & 0 & 14 & 10 & 0 & 40 & 17 & 44 \\
\hline
\end{tabular}

* Pre: Preoperative period; ${ }^{* *}$ Post: Last follow-up; CPA: Coronal plane angle; SPA: Sagittal plane angle; AOFAS: American Orthopaedic Foot and Ankle Society. 
to normal joint contours with a $4.5 \mathrm{~mm}$ full radius resector, $6.0 \mathrm{~mm}$ burr and angled curettes. Fixation was achieved through diagonal and transmalleolar $2 \times 5$ $\mathrm{mm}$ headless titanium compression screws (Acutrak ${ }^{\mathrm{TM}}$ $6 / 7 \mathrm{~mm}$ headless screw, Acumed, Oregon), one from the medial and one from the lateral with the ankle in the appropriate arthrodesis position. Fluoroscopy was used to control the position and all patients were mobilized with a non-weight bearing short-leg cast during the first six weeks. Between the sixth and $10^{\text {th }}$ weeks, they were mobilized with weight-bearing with a walking cast. The cast was removed at the $10^{\text {th }}$ week. Patients were allowed to walk with weight-bearing only when union was achieved.

\section{Statistical analysis}

SPSS version 15.0 (SPSS Inc., Chicago, IL) was used for statistical analysis. Kolmogorov-Smirnov test was used to assess the consistency of the data with normal distribution. Intergroup independent sample $t$-test was used to elaborate on parametric measurements. Non-parametric measurements were performed using the Wilcoxon and the Mann-Whitney U test. Statistical significance level was set at $\mathrm{p}<0.05$ for all tests.

\section{RESULTS}

Mean follow-up period was 59.3 months (range 36 to 92 months). Radiographic union was achieved in 21 of 22 ankles $(95.4 \%)$ and mean clinical time to union was $10.3 \pm 3.5$ weeks (range 6.6 to 13.8 weeks). The preoperative coronal plane tibiotalar angle of $6.6 \pm 5.5^{\circ}$ decreased to $2.3 \pm 2.1^{\circ}$ postoperatively with a statistically significant difference $(\mathrm{p}<0.05)$. The sagittal plane tibiotalar angle was measured as $17 \pm 4.9^{\circ}$ preoperatively and as $17 \pm 4.5^{\circ}$ postoperatively with no statistically significant difference $(p=0.542)$ (Table II).

The mean AOFAS scores increased from $8.1 \pm 10.2$ to $35 \pm 6.3$ for pain scores and from $21.3 \pm 5.5$ to $43.4 \pm 3.8$ for functional scores with a statistically significant difference $(\mathrm{p}<0.001)$.

Hardware irritation was not observed in any patient. In two patients, guide wire breakage developed during screw placement, but this did not require intervention. In one patient, open surgical method was used to apply autografting and refixation due to nonunion. One patient had subtalar joint pain in the lateral foot at the level of the sinus tarsi postoperatively and was closely monitored.

\section{DISCUSSION}

According to the significant outcomes of this study, HCSs provided high union rates (95.4\%), distinct improvement in AOFAS scores, and decreased implant removal rates due to symptomatic and prominent metalwork.

Arthroscopic ankle arthrodesis has been widely preferred due to being a less invasive approach allowing shorter time to union, higher rate of union and lower complication rate compared to open ankle arthrodesis. These result in reduced postoperative pain and shorter hospital stay. ${ }^{[5,9-11]}$

Despite the significant advantages, arthroscopic ankle arthrodesis has a long learning curve and is technically demanding. Several problems have become more evident with increased use. ${ }^{[4-6,9]}$ These are prominent metalwork irritation, inadequate compression in the arthrodesis area and screw placement problems. In general, cancellous screws are used for fixation in arthrodesis procedures. The heads of these cancellous screws cause irritation and pain as the subcutaneous tissue is thin particularly in the medial of the ankle. In these cases, it is necessary to remove the screw, which results in increased risk of nonunion ${ }^{[9]}$ Previous studies have reported secondary surgery for the removal of symptomatic metalwork in 9 to $31 \%$ of cases. ${ }^{[4,7]}$ In vitro studies have showed that HCSs provide better compression than other screw types. ${ }^{[12]}$ In our study, treatment was applied using HCSs and none of the patients developed screw head irritation.

Acutrak $^{\mathrm{TM}}$ system presents a tapered profile to allow more bone contact with each turn, and a variable pitch, with a larger leading pitch. The differential pitch leads to interfragmentary compression from the point where the threads are engaged in both fragments until screw advancement is limited by the position of the tip, or of the base, or by insertion torque. The ability to close an interfragmentary gap is therefore less than that of a headed, partially threaded screw, so it is imperative that the bone surfaces are apposed by external compression prior to screw insertion. Acutrak $^{\mathrm{TM}}$ screws give comparable or even superior compression with both synthetic and cadaver bone under laboratory conditions. ${ }^{[4,12]}$

In the current study, mean clinical time to union was $10.3 \pm 3.5$ weeks, which was in conformity with reported values in the literature. ${ }^{[9]}$ The nonunion rate in our study was within the range described in other studies, with quoted figures between 3\% and 15\%.[4] Nonunion was determined in one patient (4.5\%).

High coronal and sagittal tibiotalar angles of above $15^{\circ}$ are accepted as a contraindication for arthroscopic arthrodesis. ${ }^{[5]}$ Despite this, arthroscopic ankle arthrodesis can be used to correct the angles sufficiently, including cases of advanced varus and 
valgus deformities. ${ }^{[10]}$ In the current study, sufficient correction was established in the coronal plane. The preoperative coronal plane tibiotalar angle of $6.6 \pm 5.5^{\circ}$ was reduced to $2.3 \pm 2.1^{\circ}$ postoperatively. As there were no high preoperative sagittal plane deformities, there was no significant change. In their study, Odutola et al. ${ }^{[4]}$ achieved the correct foot alignment (neutral flexion and from $0^{\circ}$ up to $5^{\circ}$ of hindfoot valgus) in $84 \%$ of patients.

The limitations of this study are the small sample size and the lack of a control group.

In conclusion, the use of HCSs is appropriate in the ankle joint as they provide successful fixation whilst not causing screw head irritation or pain.

\section{Declaration of conflicting interests}

The authors declared no conflicts of interest with respect to the authorship and/or publication of this article.

\section{Funding}

The authors received no financial support for the research and/or authorship of this article.

\section{REFERENCES}

1. Haddad SL, Coetzee JC, Estok R, Fahrbach K, Banel D, Nalysnyk L. Intermediate and long-term outcomes of total ankle arthroplasty and ankle arthrodesis. A systematic review of the literature. J Bone Joint Surg [Am] 2007;89:1899-905.

2. Oğuz E, Kömürcü M, Yıldız C, Kürklü M, Ateşalp S. Ateşli silah yaralanmasına bağlı ayak bileği sorunlarında İlizarov eksternal fiksatörü ile artrodez uygulamaları.
Eklem Hastalik Cerrahisi 2003;14:67-73.

3. Nielsen KK, Linde F, Jensen NC. The outcome of arthroscopic and open surgery ankle arthrodesis: a comparative retrospective study on 107 patients. Foot Ankle Surg 2008;14:153-7.

4. Odutola AA, Sheridan BD, Kelly AJ. Headless compression screw fixation prevents symptomatic metalwork in arthroscopic ankle arthrodesis. Foot Ankle Surg 2012;18:111-3.

5. Salvi D, Schembri PJ, Sciberras A, Harris DJ. Evolutionary history of the Maltese wall lizard Podarcis filfolensis: insights on the 'Expansion-Contraction' model of Pleistocene biogeography. Mol Ecol 2014;23:1167-87.

6. Tandogan NR, Kaya A, Demirors H, Tuncay C, Hersekli M, Akpinar S. Arthroscopic ankle arthrodesis in a neuropathic ankle. Eklem Hastalik Cerrahisi 2001;12:209-14.

7. Abicht BP, Roukis TS. Incidence of nonunion after isolated arthroscopic ankle arthrodesis. Arthroscopy 2013;29:949-54.

8. Atik OŞ. Are all case reports worth publishing? Eklem Hastalik Cerrahisi 2016;27:61.

9. Yoshimura I, Kanazawa K, Takeyama A, Ida T, Hagio T, Angthong $\mathrm{C}$, et al. The effect of screw position and number on the time to union of arthroscopic ankle arthrodesis. Arthroscopy 2012;28:1882-8.

10. Dannawi Z, Nawabi DH, Patel A, Leong JJ, Moore DJ. Arthroscopic ankle arthrodesis: are results reproducible irrespective of pre-operative deformity? Foot Ankle Surg 2011;17:294-9.

11. Townshend D, Di Silvestro M, Krause F, Penner M, Younger A, Glazebrook M, et al. Arthroscopic versus open ankle arthrodesis: a multicenter comparative case series. J Bone Joint Surg Am 2013;95:98-102.

12. Wheeler DL, McLoughlin SW. Biomechanical assessment of compression screws. Clin Orthop Relat Res 1998;350:237-45. 